\title{
Nest Site Selection by Mountain Plovers in Northcen- tral Montana
}

\author{
SALLY L. OLSON AND DANIEL EDGE
}

\begin{abstract}
Nest site selection of the mountain plover (Charadrius montanus) was studied on the Charles M. Russell National Wildlife Refuge, Montana, during 1982. Vegetative characteristics of 26 nest sites, all on prairie dog towns, were compared to a random sample of plots on prairie dog towns and adjacent areas. Total plant cover, grass cover, big sagebrush (Artemisia tridentata) and prickly pear (Opuntia polyacantha) density, and mean vegetation height were all significantly greater $(P<0.05)$ in areas adjacent to prairie dog towns than at the nest sites; litter cover and fringed sagewort (Artemisia frigida) density were greater at the nest site. Within prairie dog towns, erosion pavement cover and mean vegetation height were greater on randomly sampled plots than at the nest sites. Mountain plovers select nest sites on prairie dog towns in patches of greater cover and less vegetative height than occur at random sites within the towns. Prairie dog towns offer islands of suitable mountain plover habitat and should be maintained on the Refuge, especially in light of the prairie dog control programs conducted on adjacent lands.
\end{abstract}

Mountain plovers (Charadrius montanus) typically breed in upland shortgrass prairies of the western Great Plains, primarily in Colorado, Wyoming, and Montana (Graul and Webster 1976). Nearly all descriptions of mountain plover breeding habitat have portrayed nesting sites as level, heavily grazed areas with short vegetation, usually dominated by blue grama grass (Bouteloua gracilis) (Graul 1975, Johnson and Spicer 1981, Wallis and Wershler 1981). Graul (1975) described vegetation type, slope, and characteristics of mountain plover nest sites in northeastern Colorado. Other studies described nest scrapes and lining materials (Hoskin 1893, Goodrich 1945:195, Laun 1957) but recorded no general habitat measurements. On the Charles M. Russell National Wildlife Refuge, in northcentral Montana, Knowles et al. (1982) found that mountain plovers selectively use black-tailed prairie dog (Cynomys ludovicianus) towns for breeding, nesting, feeding, and rearing young. This affinity for prairie dog towns has not been noted elsewhere. They also found that horizontal visibility and amount of bare areas were significantly greater inside towns than in adjacent areas. Declining populations and habitat loss throughout wide portions of mountain plover range intensify the need for improved knowledge of habitat requirements.

The objective of this study was to quantify vegetative characteristics at mountain plover nest sites, and compare these characteristics to random sites on prairie dog towns and adjacent areas.

\footnotetext{
Authors are research assistant and wildlife research specialist, School of Forestry, University of Montana. Missoula 59812. At the time of the research, the senior author was a graduate student, Montana Cooperative Wildlife Research Unit, University of Montana.

Funding for this study was provided by the Chapman Fund, The Five Valleys Chapter of the National Audubon Society, Sigma Xi, and the Charles M. Russel National Wild life Refuge. Logistical support was provided by the Montana Cooperative Wildlife Research Unit. We thank I.J. Ball, D. Jenni, B.W. O'Gara and E.E. Willard for reviewing the original manuscript.

Manuscript accepted November 20, 1984
}

\section{Study Area}

The study area is located in northcentral Montana within the Western Unit of the Charles M. Russell National Wildlife Refuge, comprising $560 \mathrm{~km}^{2}$ on the north side of the Missouri River. The area, in Phillips County, is approximately $100 \mathrm{~km}$ northeast of Lewistown and $100 \mathrm{~km}$ southwest of Malta.

This area is an eroded plateau, elevation $920 \mathrm{~m}$, characterized by rugged timbered breaks, deep-cut coulees, steep ridges, and river bottoms. Major ridgetops, which are flat and broad, run primarily north and south and broaden progressively to form rolling mixedgrass prairie toward the northern boundary of the Refuge.

Ponderosa pine (Pinus ponderosa), interspersed with Rocky Mountain juniper (Juniperus scopulorum) thickets, dominates north-facing slopes. The principal plant species found on the broad ridgetops are western wheatgrass (Agropyron smithii), blue grama, prickly pear (Opuntia polyacantha), fringed sagewort (Artemisia frigida), and big sagebrush (A. tridentata). Knowles (1982) described the climate, topography, and vegetation of the area.

Black-tailed prairie dog towns, which occupy about $1.6 \%$ of the study area, are typically located on level upland sites and are considered by Knowles et al. (1982) to represent a distinct habitat. Prickly pear, fringed sagewort, blue grama, western wheatgrass, and a variety of forbs prevail and are interspersed with areas of erosion pavement.

Mountain plover nests were studied on 9 major upland prairie dog towns on the north side of the Missouri River. The towns ranged in size from 6 ha to 307 ha, and all were grazed by cattle under a 4-pasture rest-rotation grazing system.

\section{Methods}

Field work was conducted from 8 April to 1 September 1982. Nest sites were flagged after nests hatched, or were abandoned or destroyed. Data collection began as soon as all nests were terminated to prevent disturbing nests. Vegetation changes that occurred between nest initiation and nest site measurement were assumed to be similar for all nest and random plots. Vegetation within a $1-m^{2}$ frame was measured at each nest site. In addition, for each nest site, vegetation at 10 random plots on the prairie dog town, and 10 random plots in areas adjacent to prairie dog towns, was similarly measured. Prairie dog town borders were usually well defined to an abrupt vegetation change; adjacent plots were outside the prairie dog town, on level, grazed areas. Any plots that fell on steep-sided juniper slopes were discarded. The 3 groups to be compared were therefore defined as nest plots, prairie dog town plots, and adjacent plots. The nest scrape, or the random point, was used as the plot center. Plot variables measured or estimated were: (1) percent grass cover, (2) percent total plant cover, (3) prickly pear density, (4) big sagebrush density, (5) fringed sagewort density, (6) forb density, (7) mean vegetation height $(\mathrm{cm}),(8)$ rock 
( $\geq 8 \mathrm{~cm}$ diameter) density, (9) percent litter-hummock cover (including the windblown lichen Parmelia spp. and the low matforming Phlox hoodii), and (10) percent erosion pavement cover. Distance to the nearest prairie dog burrow was measured, and the distance to the nearest rock over $8 \mathrm{~cm}$ in diameter was recorded if it was within $10 \mathrm{~m}$ of the nest or random point.

Data were collected, beginning on 12 July, for the 26 nest plots, for 260 random prairie dog town plots, and 260 random adjacent plots. Each variable within the 10 random prairie dog town plots and adjacent plots was averaged for each nest plot, resulting in a sample size of 26 for each of the 10 variables for all groups.

In an effort to control the experiment-wide error rate, a one-way multivariate analysis of variance was attempted, but the assumption of homogeneous variance-covariance matrices was not met. Therefore, a Kruskal-Wallis nonparametric analysis of variance was run for each variable to test the hypothesis of equal distributions between the 3 groups. When variables were significantly different between the groups, a priori tests were run to determine which groups were different from nest sites.

\section{Results}

Twenty-six nests were found between 2 May and 10 July 1982 on 9 prairie dog towns. Variable means differed among the 3 groups (Table 1). Most striking differences between nest plots and prairie

Table 1. Characteristics of mountain plover nest plots, prairie dog town plots, and adjacent plots on the Charles M. Russell National Wildlife Refuge.

\begin{tabular}{|c|c|c|c|c|c|c|}
\hline \multirow[b]{3}{*}{ Variable } & \multicolumn{4}{|c|}{$\begin{array}{l}\text { Dog Town } \\
\text { Plots }\end{array}$} & \multicolumn{2}{|c|}{ Adjacent Plots } \\
\hline & \multicolumn{2}{|c|}{$(N=26)$} & \multicolumn{2}{|c|}{$(\mathrm{N}=26)$} & \multicolumn{2}{|c|}{$(N=26)$} \\
\hline & $\bar{X}$ & SD & $\vec{X}$ & SD & $\vec{X}$ & SD \\
\hline$\%$ Total plant cover & 38.65 & 14.39 & 32.77 & 10.60 & 50.23 & 10.29 \\
\hline$\%$ Erosion pavement & 26.92 & 16.74 & 42.54 & 10.29 & 28.62 & 9.50 \\
\hline$\%$ Grass cover & 14.54 & 15.66 & 14.50 & 11.28 & 32.23 & 12.62 \\
\hline Rocks $/ \mathrm{m}^{2 \mathrm{a}}$ & 0.77 & 1.50 & 0.23 & 0.43 & 0.38 & 0.57 \\
\hline Big sagebrush & & & & & & \\
\hline (plants $/ \mathrm{m}^{2}$ ) & 0.04 & 0.19 & 0.27 & 0.67 & 1.04 & 1.18 \\
\hline Fringed sagewort & & & & & & \\
\hline (plants $/ \mathrm{m}^{2}$ ) & 15.23 & 12.04 & 10.92 & 5.47 & 3.46 & 2.14 \\
\hline Forbs (plants $/ \mathrm{m}^{2}$ ) & 42.27 & 45.99 & 25.15 & 27.39 & 15.04 & 6.76 \\
\hline$\%$ Litter cover & 31.73 & 16.55 & 24.69 & 9.72 & 20.77 & 6.15 \\
\hline Prickly pear & & & & & & \\
\hline $\bar{X}$ Vegetants $\left./ \mathrm{m}^{2}\right)$ & 0.96 & 2.79 & 0.85 & 1.49 & 2.31 & 1.95 \\
\hline height $(\mathrm{cm})$ & 4.35 & 1.09 & 6.35 & 2.02 & 16.81 & 3.95 \\
\hline
\end{tabular}

${ }^{a}$ Rocks $\geq 8 \mathrm{~cm}$ in diameter.

dog town plots occurred with erosion pavement cover and forb density. Erosion pavement cover was greater on prairie dog town plots than at nest plots, and forb density was greater at the nest plots. Mean values for total plant cover, grass cover, mean vegetation height, and prickly pear density were considerably greater in adjacent plots than at the nest or the prairie dog town plots, whereas fringed sagewort density and forb density were both greater at the nest plot than on either the prairie dog town or adjacent plots.

The Kruskal-Wallis test indicated that all variables except rock density and forb density were significantly different $(P \leq 0.05)$ among the 3 groups (Table 2); these were removed from further analysis. Of the remaining 8 variables, only erosion pavement cover and mean vegetation height differed significantly between nest plots and prairie dog town plots; both were less at the nest plots than the prairie dog town plots. When nest plots were compared to adjacent plots, only erosion pavement cover, of the 8 variables, was not significantly different. Total plant cover, grass
Table 2. P-values associated with test of hypotheses of equal group distributions for mountain plover nest plots, prairie dog town plots, and adjacent plots.

\begin{tabular}{lccc}
\hline \hline Variable & All groups & $\begin{array}{c}\text { Nests vs } \\
\text { dog town } \\
\text { plots }\end{array}$ & $\begin{array}{c}\text { Nests vs } \\
\text { ajacent }^{\mathrm{b}}\end{array}$ \\
plots $^{\mathrm{c}}$
\end{tabular}

${ }^{a}$ Kruskal-Wallis Test: Nests Plots $=$ Prairie Dog Town Plots $=$ Adjacent Plots.

bMann-Whitney Test: Nest Plots = Prairie Dog Town Plots.

'Mann-Whitney Test: Nest Plots $=$ Adjacent Plots.

${ }^{d}$ Rocks $\geq 8 \mathrm{~cm}$ in diameter.

cover, big sagebrush cover, prickly pear cover, and mean vegetation height were all significantly greater in adjacent plots than at nest plots; fringed sagewort density and litter cover were significantly greater at the nest plot. No significant difference was found in distance to nearest prairie dog burrow between nest plots and prairie dog plots; mean distance was $7.3 \mathrm{~m}(\mathrm{SD}=3.7)$ from the nest plot and $6.8 \mathrm{~m}(\mathrm{SD}=4.2)$ from the prairie dog town plot. Thirtyone percent of the nest plots had at least 1 rock present in the plot, and the nearest rock was a mean distance of $8.5 \mathrm{~cm}(S D=9.4)$ from the nest. Of the $13 \%$ of prairie dog town plots with rocks present, the nearest rock was an average of $26 \mathrm{~cm}(S D=17.8)$ from plot center, and $18 \%$ of the adjacent plots had rocks at a mean distance of $28 \mathrm{~cm}(\mathrm{SD}=16.0)$.

\section{Discussion and Conclusions}

Habitat found in prairie dog towns appears to be necessary for mountain plovers to breed on the Charles M. Russell National Wildlife Refuge, a requirement not noted elsewhere for this species. Mountain plovers apparently did not select bare areas for nest sites per se; percent erosion pavement at the nest site was comparable to that in adjacent areas. The greater amount of litter at the nest site, although not significant, may in part be due to the presence of nest lining materials in and around the nest scrape. Although forbs and fringed sagewort were not found in significantly greater densities at the nest sites than on the towns in general, 21 nests were placed close (less than $10 \mathrm{~cm}$ ) to a clump of fringed sagewort or forbs which was never high or dense enough to conceal the incubating bird. In 7 cases, nests were placed beside or close to large, flat rocks. The tendency to nest by a conspicuous object is a noted tendency in Charadriidae species (Graul 1975). Long-billed curlews (Numenius americanus) selected nest sites near objects such as manure piles, rocks, or bare dirt mounds. This may function to make the bird less conspicuous, particularly in areas with scant vegetation (Allen 1980).

The most striking differences between prairie dog towns and adjacent areas are decreased vegetative height in towns compared to adjacent areas and differences in plant species composition (Bonham and Lerwick 1976, Hansen and Gold 1977). Knowles (1982) found significantly greater horizontal visibility in towns than in adjacent areas. One or more of these features may account for the suitability of dog towns as mountain plover habitat. Mountain plovers evolved on short-grass prairie of the western Great Plains, and therefore select short vegetation for breeding areas. All townsites on the Refuge occur within shrub-grassland or grassland habitats, and on the Western Unit, nearly all towns containing breeding plovers are found within the big sagebrush-blue grama habitat type (Knowles 1982). Prairie dog towns appear to be 
"islands" of habitat within an area not otherwise suited for mountain plovers.

Prairie dog activities alter vegetative composition in a town over time (Hansen and Gold 1977, Knowles 1982). The most noticeable changes are in increased plant diversity on towns, and selection against tall plants and shrub species by continuous clipping, which creates a low vegetation profile with many bare areas. We noted that big sagebrush was absent from prairie dog towns or, if present, occurred in a stunted and defoliated condition. Species like western wheatgrass and big sagebrush are selectively clipped over buffalo grass (Buchloe dactyloides), blue grama, and low-growing annual or perennial forbs (Koford 1958). Prairie dog effects alone are difficult to determine because prairie dogs in most cases are closely tied to, or even dependent upon, grazing by cattle (Koford 1958, Hansen and Gold 1977, Knowles 1982). Cattle, together with prairie dogs, cause heavy use of areas, and by late summer, very little vegetation remains on the prairie dog towns. Knowles (1982) believes that cattle use as much as two-thirds of the available forage on a town. However, cattle grazing alone does not create mountain plover habitat in this area, apparently because of the persistance of woody forbs and shrubs. Mountain plovers were not found in areas of heavy cattle use without prairie dogs; $98 \%$ of all mountain plover sightings during this study were on prairie dog towns although all potential habitat was surveyed (Olson 1984). Mountain plovers appear to select for a low vegetative profile not only for nesting but for all activities during the breeding season. Birds could not be driven from the towns. If flushed, they would always land on the town, a behavior also noted by Knowles et al. (1982).

Maintaining these towns is crucial to maintain breeding mountain plovers on the Charles M. Russell National Wildlife Refuge. Widespread prairie dog control off of the Refuge may further limit suitable breeding habitat for mountain plovers in Montana.

\section{Literature Cited}

Allen, J.A. 1980. The ecology and behavior of the Long-billed Curlew southeastern Washington. Wildl. Monogr. 73.

Bonham, C.D., and A. Lerwick. 1976. Vegetation changes induced prairie dogs on shortgrass range. J. Range Manage. 29:221-225.

Goodrich, A.L. 1945. Birds in Kansas. Rep. of the Kansas State Board Agr. Vol. LXIV, 267.

Graul, W.D. 1975. Breeding biology of the Mountain Plover. Wilson B1 87:6-31.

Graul, W.D., and L.E. Webster. 1976. Breeding status of the Mount: Plover. Condor. 78:265-267.

Hansen, R.M., and I.K. Gold. 1977. Blacktail prairie dogs, desert cottc tails and cattle trophic relations on shortgrass range. J. Range Mana 30:210-214.

Hoskin, H.G. 1893. Nesting of the Mountain Plover. Oologist 10:230.

Johnson, T.B., and R.B. Spicer. 1981. Mountain Plovers on the $N$ Mexico-Arizona border. Continental Birdlife. 2:69-73.

Knowles, C.J. 1982. Habitat affinity, populations, and control of bla tailed prairie dogs on the Charles $M$. Russell National Wildlife Refu Ph.D. Diss. Univ. Montana, Missoula.

Knowles, C.J., C.J. Stoner, and S.P. Gieb. 1982. Selective use of bla tailed prairie dog towns by Mountain Plovers. Condor. 84:71-74.

Koford, C.B. 1958. Prairie dogs, whitefaces and blue grama. Wildl. Mc gor. 3.

Laun, C.H. 1957. A life history study of the Mountain Plover (Eupc montana Townsend), on the Laramie Plains, Albany County, Wyomi M.S. Thesis, Univ. Wyoming, Laramie.

Olson, S.L. 1984. Density and distribution, nest site selection, and activ of the Mountain Plover on the Charles M. Russell National Wild] Refuge. M.S. Thesis, Univ. Montana, Missoula.

Wallis, C.A., and C.R. Wershler. 1981. Status and breeding of Mount; Plovers (Charadrius montanus) in Canada. Can. Field-Nat. 95:133-1

New!

\section{Vegetation Changes on Western Rangelands}

by Farrel A. Branson

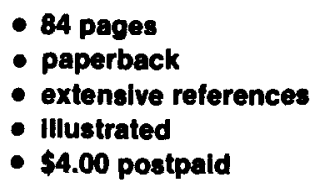

This book provides a comprehensive source of information on vegetation changes that have occurred on western rangelands during the past 100 years. It is illustrated with maps and photographs. The comments of one reviewer of the manuscript are as follows:

"It is a very good source of information on vegetation types for students as well as range professionals. It would be a good text for range community courses and portions could be used for selected assignments in other range courses. It brings together the primary references and provides so much more information to date than our present texts. I strongly believe that it will be a well-referred source. It would also improve the image of the range profession as one that is tremendously knowledgeable about the resources it manages. Branson's style of writing is good. It is straight forward and uncomplicated."Dr. M. Hironaka, University of Idaho, Moscow, Idaho.

Range professors and students, private and public range managers, soil conservationists, wildlife managers, and others will find the book a valuable contribution to their libraries. Available from the Society for Range Management 2760 W. Fifth Ave, Denver, CO 80204. 